\title{
ISLAMIC BANK TRUST: THE ROLES OF RELIGIOSITY, PERCEIVED VALUE AND SATISFACTION
}

\begin{abstract}
Purpose

This study aimed to examine the relationship between trust and its antecedents, i.e. customer satisfaction, perceived value and religiosity. The moderating role of religiosity in the relationships among perceived value, satisfaction and trust were also investigated in this study.

\section{Design/Methodology/Approach}

This study was carried out in West Sumatra, Indonesia. The respondents of this study were Islamic bank customers from 5 areas in West Sumatera, Indonesia. The data were collected through the survey method. After doing some preliminary analyses, we employed 390 usable responses based on the analyses. Covariance-Based Structural Equation Modeling (CB-SEM) was employed to analyze the data.
\end{abstract}

\section{Findings}

This study found that religiosity had significant impact on perceived value, customer satisfaction and trust. Perceived value and customer satisfaction were also significant antecedents of trust. Moreover, this study found the significant moderating impact of religiosity on the relationship between perceived value and trust, and also the relationship between customer satisfaction and trust.

\section{Research Limitations/Implications}

This cross-sectional study was conducted in a single country. Accordingly, this study might have a limitation in the result generalization. Moreover, this study only focused on three antecedents of trust: religiosity, satisfaction and perceived value. Therefore, for future researchers, we suggest conducting a longitudinal study in some Muslim countries such as Malaysia, Brunei Darussalam and Middle East countries. We also suggest employing other antecedents of customer trust, such as customer engagement and customer socio-culture.

\section{Practical implications}

Considering the research findings, the managers of Islamic banks will have input on how to improve their customers' trust by giving more attention to customer religiosity, perceived value and satisfaction. They can develop programs to increase customer perceived value and satisfaction like a reward program to increase customer trust.

\section{Originality/Value}

A more comprehensive model of the relationships among religiosity, perceived value, satisfaction and trust was addressed in this study. The significant moderating role of religiosity in the relationships among perceived value, satisfaction and trust which had been neglected previously was also highlighted in this study.

Keywords: Trust; Customer Satisfaction, Perceived Value; Religiosity; Islamic Bank; Indonesia

JEL: M31 


\section{Introduction}

Islamic bank industry has been an important business sector in Muslim countries lately. Indonesia as one of the countries with biggest Muslim population in the world has introduced Islamic banks since 1991. Bank Muamalat is the oldest Islamic bank in Indonesia. Moreover, the government announced the enactment of UU No. 212008 about Islamic bank in 2008. After the enactment of this regulation, the number of Islamic banks has increased significantly. The data show that Indonesia had 197 units of Islamic banks in 2014 (Otoritas Jasa Keuangan, 2017). Unfortunately, the number of banks has not been in line with the market share. The market share of Islamic banks has been still low. For instance, in March 2019 the market share of Islamic banks was only 5.94\% (Otoritas Jasa Keuangan, 2019).

Customer trust is a key point in managing a business today (Al-Ansi \& Han, 2019). Customer trust will lead to customer loyalty. Customer trust has some influential factors such as customer satisfaction (Yao, Qiu, \& Wei, 2019), customer perceived value (Yuen, Wang, Wong, \& Zhou, 2018) and religiosity (Lo Turco \& Maggioni, 2018). This study aimed to investigate the direct relationship among religiosity, customer satisfaction, perceived value and customer trust. Moreover, this study also examined the moderating effect of religiosity on the relationship between perceived value and trust and the relationship between customer satisfaction and trust which were overlooked in the previous studies. Some studies highlighted the mediating effect of religiosity on customer satisfaction (Zamani-Farahani \& Musa, 2012; Eid \& El-Gohary, 2015); however, they failed to address the moderating role of religiosity in the relationship between perceived value and trust and the relationship between customer satisfaction and trust especially in Islamic banking sector.

Indonesia as one of the countries with biggest Muslim population becomes a potential market for Islamic banks (Darsono, Sakti, Suryanti, Astiyah, \& Darwis, 2017). One of the potential provinces is West Sumatera. Most of the people in West Sumatera are Muslim and this province has motto "Adat basandi syarak, syarak basandi kitabullah". It means that the people in West Sumatra use Islam as the way of life. They will comply with Islamic rules when they do their activities including using banking services (Darsono et al., 2017). Trust in Islamic banks is very important for Islamic bank companies if they want to attract more customers (Fungáčová, Hasan, $\&$ Weill, 2019). When Islamic bank companies get customer trust, it means that they will get more customers and it will have impact on company profits. Therefore, this study investigated the antecedents of trust, such as perceived value, satisfaction and religiosity, which are important to increase customer trust. Trust will lead to customer loyalty and at the end it will have impact on company profits (Kingshott, Sharma, \& Chung, 2018).

According to Gursoy, Altinay, and Kenebayeva (2017), religiosity is a significant factor in shaping the effect of customers' value on their behavior. Trust is also related to customer behavior (Al-Ansi \& Han, 2019; Minton, 2019). In fact, the moderating role of religiosity in the relationship between perceived value and satisfaction has been examined in previous studies (Aji, Muslichah, \& Seftyono, 2020). Akhtar, Jin, Alvi, and Siddiqi (2020) highlighted the moderating effect of religiosity on the conflicting halal attributes and attitude ambivalence relationship which is related to satisfaction and trust. Nevertheless, the moderating role of religiosity in the relationships among perceived value, satisfaction and trust had been neglected especially in Halal business context (Briliana \& Mursito, 2017). Therefore, the gap in this context was still open.

This study reveals some theoretical contributions and managerial implications. There are some theoretical contributions of this study. The first one is that this study has developed a more comprehensive model regarding the relationships among religiosity, perceived value, customer 
satisfaction and trust which previously had been overlooked (Fungáčová et al., 2019; Yasin, Liébana-Cabanillas, Porcu, \& Kayed, 2020). For instance, Fungáčová et al. (2019) examined the relationship between trust and religious value and Kingshott et al. (2018) investigated the relationship between satisfaction and trust; however, a more comprehensive model of trust antecedents was neglected. This study, therefore, gave explanation of how customer trust is influenced by several antecedents, such as satisfaction, perceived value and religiosity in a more complex model. The second contribution is that the moderating role of religiosity in the relationship between perceived value and trust has been revealed in this study. This study found that religiosity strengthened the relationship between perceived value and trust. To the best of our knowledge, the relationship had still been overlooked in previous studies (Minton, 2019; Yasin et al., 2020). The third contribution is that this study also found that religiosity was a significant moderating variable in the relationship between customer satisfaction and trust which had been neglected in previous studies (Kingshott et al., 2018). Religiosity refers to customers' Islamic belief and practice. The customers with high religiosity will have better trust in Islamic banks because they believe that Islamic banks comply with Islamic rules. Accordingly, religiosity will strengthen the relationships among perceived value, customer satisfaction and trust. Thus, this study gives insights into how religiosity influences the relationship between trust and its antecedents.

Moreover, this study also has contributions to managerial decision making. The managers of Islamic banks in Indonesia need to give more attention to the antecedents of trust. Accordingly, when they want to maintain customer trust, they should concern with the antecedents of trust such as perceived value, satisfaction and religiosity. The most important factor in influencing trust is perceived value; therefore, the Islamic bank managers have to improve customer perceived value and customer satisfaction when they want to increase customer trust. In fact, perceived value and satisfaction are affected by religiosity; therefore, the managers also have to pay attention to customer religiosity to increase customer trust. Finally, this study will help society understand Islamic bank trust and its antecedents including religiosity.

\section{Literature Review}

\subsection{Religiosity}

Religiosity can be defined as "the degree to which an individual is committed to a certain religious group" (Zamani-Farahani \& Musa, 2012, p. 803). Religiosity is an individual's degree of commitment to his/her religion - in other words, it is "a way of life which results in individual or social values and attitudes" (Aji et al., 2020, p. 6). More clearly, Achour, Mohd Nor, and MohdYusoff (2016, p. 1302) mention, "Islamic religiosity is the commitment to the fundamentals of the Islamic religion empirically and theoretically through the fulfilment of Allah's rights, the protection of the rights of others, following Allah's orders, avoiding bad acts, and performing worship". Accordingly, religiosity reflects customers' commitment to follow their religion and do worship according to Allah's orders. Previous studies revealed that the different aspects of customer behavior can be identified depending on their religiosity levels (Jamshidi \& Hussin, 2016). Some previous studies revealed that religiosity affected an individual's attitudes and behavior including satisfaction (Joshanloo, 2016), purchasing behavior (Briliana \& Mursito, 2017), trust (Fungáčová et al., 2019) and perceived value (Jamal \& Sharifuddin, 2015; Agarwala, Mishra, \& Singh, 2019). 


\subsection{Perceived Value}

Perceived value refers to customers' perception when they compare benefits and sacrifices in acquiring goods or services (Yuen et al., 2018; Aw Eugene, Basha Norazlyn, Ng Siew, \& Sambasivan, 2019). The perceived value is good when the benefits are greater than the sacrifices. According to Suryani (2015), the perceived value of Islamic bank customers consists of four values: functional value, emotional value, social value and spiritual value. Moreover, Vera and Trujillo (2013) mention that perceived value relates to customers' judgement on what they received is superior to what they paid to get the products or services. Accordingly, we argue that perceived value is customers' valuation on the benefit of product or service compared to the cost of the product or service. Moreover, perceived value is not only functional value but also other value such as spiritual value. Therefore, customers will also perceive the products based on the spiritual value.

\subsection{Customer Satisfaction}

Customer satisfaction is customers' overall perception of the product or service performance (ElAdly, 2018). According to Miranda, Tavares, and Queiró (2017), customer satisfaction refers to pleasure or disappointment feeling of the customer after comparing between product or service expectation and its performance. Customer satisfaction might be influenced by some factors such as the customer perceived value (Kasiri, Guan Cheng, Sambasivan, \& Sidin, 2017) and the customer religiosity (Eid \& El-Gohary, 2015).

\subsection{Trust}

Trust refers to a psychological state which comprises an individual's intention to accept vulnerability based upon positive expectations of the intention or behavior of another (Zhang, Yan, \& Zhang, 2018). Trust can also be said “one person's belief that another's word or promise is reliable and that the person will fulfill his or her obligations in an exchange relationship" (Cheshin, Amit, \& van Kleef, 2018, p. 99). In the context of banking, Fungáčová et al. (2019) suggest that in a bank trust is closely associated with money handling in the bank. More clearly, Yuen et al. (2018) explain that trust is related to customers' belief that the bank provides goods or services which meet their expectations. Accordingly, trust is defined as customers' belief in a company's ability, integrity and benevolence that can increase their intention to depend on the company's product(s) or brand(s) (Alalwan, Dwivedi, \& Rana, 2017, p. 103). In addition, there are some influential factors in trust such as satisfaction (Al-Ansi \& Han, 2019), perceived value (Itani, Kassar, \& Loureiro, 2019) and religiosity (Minton, 2019).

\subsection{Religiosity and Perceived Value}

Some previous studies assert that religiosity relates to customer perceived value (Bakar, Lee, \& Rungie, 2013; Amaliah, Aspiranti, \& Purnamasari, 2015; Eid \& El-Gohary, 2015; Jamal \& Sharifuddin, 2015; Aji et al., 2020). For example, Aji et al. (2020) investigated the relationship between religiosity and perceived Islamic value. They found that religiosity influenced customer perceived Islamic value. Moreover, Gursoy et al. (2017) examined the relationship between religiosity and entrepreneur's value. They found that religiosity had significant moderating impact on the relationship between value and the entrepreneur's innovation behavior. Briliana and Mursito (2017) also found that religiosity was a significant antecedent of attitude toward Halal cosmetics. 
Even though only limited studies investigated this relationship, religiosity might influence how a customer perceives the benefit of a product or service. Therefore, we argue that religiosity is an antecedent of perceived value. So, we proposed that religiosity has significant and positive impact on Islamic bank perceived value (H1).

\subsection{Religiosity and Customer Satisfaction}

Religiosity is also related to customer satisfaction (Amaliah et al., 2015; Eid \& El-Gohary, 2015; Joshanloo, 2016). Eid and El-Gohary (2015) investigated the moderating effect of religiosity on the relationship between perceived value and customer satisfaction. Religiosity strengthened the relationship between perceived value and customer satisfaction. Suhartanto, Marwansyah, Muflih, Najib Moh, and Faturohman (2019) also assert that religiosity is a significant antecedent of customer satisfaction. Accordingly, we argue that religiosity is closely related to satisfaction. However, studies that had investigated the direct relationship between religiosity and customer satisfaction were still limited (Suhartanto et al., 2019). Therefore, we proposed a hypothesis that religiosity is a significant and positive antecedent of customer satisfaction $(\mathrm{H} 2)$.

\subsection{Religiosity and Trust}

Some prior studies highlighted that religiosity has a relationship with trust (Liu \& Minton, 2018; Lo Turco \& Maggioni, 2018). Lo Turco and Maggioni (2018) found that religiosity had impact on bilateral trust in trade. Moreover, Liu and Minton (2018) and Minton (2019) examined the significant impact of religious brand positioning on trust. Religious brand positioning related to customer religiosity. Bègue (2002) also revealed that religious commitment was a positive and significant antecedent of brand trust. Religious commitment was also related to religiosity. Even though the previous studies did not address religiosity as the antecedent of trust, we argued that religiosity is related to trust. Therefore, we posited a hypothesis that religiosity is a significant and positive antecedent of customer trust (H3).

\subsection{Perceived Value and Customer Satisfaction}

Perceived value is an antecedent of customer satisfaction (El-Adly, 2018; Karjaluoto, Shaikh, Saarijärvi, \& Saraniemi, 2018; Itani et al., 2019; Jeong \& Kim, 2019). For instance, Carlson, Rahman, Taylor, and Voola (2017) examined the relationship between the perception of value and customer satisfaction. They found that perceived value had significant and positive impact on customer satisfaction. Moreover, Eid and El-Gohary (2015) also found that perceived value had significant effect on tourist satisfaction. Accordingly, when a customer got a high perceived value on the product or service performance, they would be satisfied with the product or service. Rahayu, Setiawan, Irawanto, and Rahayu (2020) investigated the relationship between perceived value and customer satisfaction. They revealed that customer satisfaction was significantly affected by customer perceived value. Therefore, we argued that perceived value is a direct antecedent of customer satisfaction. From this point of view, we proposed a hypothesis that perceived value is a positive and significant influential factor in customer satisfaction (H4). 


\subsection{Perceived Value and Trust}

Some prior studies highlighted that perceived value is an antecedent of trust (Wongkitrungrueng \& Assarut, 2018; Al-Ansi \& Han, 2019; Sharma \& Klein, 2020). For instance, Al-Ansi and Han (2019) assert that a customer will trust a product or service when they have perceived the high value of it. In contrast, other authors also argue that trust might have a direct impact on perceived value (Bonsón Ponte, Carvajal-Trujillo, \& Escobar-Rodríguez, 2015; Konuk, 2018). They assert that trust is an antecedent of perceived value. When the customers trust the product or service, they will perceive the high value of the product or service. Accordingly, both relationships are still in debate. We argued that the more plausible argument is that perceived value will lead to customer trust. Therefore, this study investigated this relationship and we proposed a hypothesis that perceived value is a positive and significant antecedent of customer trust (H5).

\subsection{Customer Satisfaction and Trust}

Customer satisfaction has a relationship with trust (Al-Ansi, Olya, \& Han, 2018; Kingshott et al., 2018; Al-Ansi \& Han, 2019; Yao et al., 2019). Some prior studies asserted that trust will lead to customer satisfaction (Al-Ansi et al., 2018; Cheshin et al., 2018; Yao et al., 2019). On the other hand, some previous studies also argued that customer satisfaction is an antecedent of trust (Kingshott et al., 2018; Al-Ansi \& Han, 2019). This debate has occurred in the literature. When customers are satisfied with a product or service, they will trust it. Then, when the customers have trusted the product or service, it might lead to their satisfaction. Both relationships are plausible; however, we argued that the more possible relationship is customer satisfaction as an antecedent of trust. It means that when the customers are satisfied with the Islamic bank services, they will trust it. Therefore, we posited that customer satisfaction has significant and positive impact on customer trust (H6).

\subsection{Religiosity, Perceived Value and Trust}

There are some previous studies which investigated the role of religiosity. Aziz, Md Husin, Hussin, and Afaq (2019) found the direct effect of religiosity on trust. Singh, Singh, Kumar, and Mathur (2021) also revealed that customers' attitudes or behavior, e.g. satisfaction and trust, were affected by their religiosity. Additionally, some studies examined the moderating role of religiosity. Eid and El-Gohary (2015); Rahayu et al. (2020) in their studies found that religiosity was a significant moderating variable in the relationship between perceived value and customer satisfaction. In line with their study, Abror, Wardi, Trinanda, and Patrisia (2019) also highlighted the role of religiosity in the relationship between Halal tourism and customer satisfaction. Furthermore, Itani et al. (2019) highlighted the relationship between perceived value and trust. Arguably, religiosity could strengthen or weaken the relationship between perceived value and trust. Meanwhile, the customers who have strong Islamic belief and consistently perform Islamic rituals would have better perceived value of Islam and it might affect their trust in Islamic bank services. Nevertheless, to the best of our knowledge, there was no study which exactly addressed the moderating role of religiosity in the relationship between perceived value and trust. Therefore, we hypothesized that religiosity is a significant moderating variable in the relationship between perceived value and trust $(\mathrm{H} 7)$. 


\subsection{Religiosity, Satisfaction and Trust}

Eid and El-Gohary (2015) elucidate that customers' attitudes and behavior such as satisfaction and trust are associated with their religiosity. In line with Eid and El-Gohary (2015), Akhtar et al. (2020, p. 502) state that "religiosity can determine customers' attitudes and behavior". Singh et al. (2021) also suggest that religiosity is related to consumer behavior, e.g. interpersonal trust. Moreover, Eid and El-Gohary (2015, p. 481) assert that "the attitudes and behavior of tourists may differ according to their religiosity". In other words, religiosity relates to satisfaction (Eid \& ElGohary, 2015; Abror, Patrisia, et al., 2019); religiosity also relates to trust (Lo Turco \& Maggioni, 2018); and satisfaction is an antecedent of trust (Kingshott et al., 2018; Al-Ansi \& Han, 2019). So, religiosity, satisfaction and trust are related. The customers with high religiosity arguably would have a different perception of their satisfaction and, accordingly, it will lead to their trust. In fact, previous studies overlooked this moderating relationship. However, religiosity might have moderating impact on the relationship between customer satisfaction and customer trust. On the basis of the explanation above, we proposed a hypothesis that religiosity has significant moderating impact on the relationship between customer satisfaction and trust (H8).

\section{Research Method}

\subsection{Population and Sample}

This study was conducted on Islamic banks' customers in West Sumatra. We employed four municipals/cities in West Sumatra as the study areas were based on the data from the Financial Services Authority report (Otoritas Jasa Keuangan, 2017). These four were chosen because they have Islamic bank branches. The data were collected from 400 respondents and after the preliminary analyses (i.e., outlier, normality, homogeneity and multicollinearity test), 390 usable questionnaires were gotten. Moreover, Structural Equation Modelling (SEM) was employed as the data analysis tool in which the number of samples should be greater than 200 (Byrne, 2010). Therefore, this study has met the number of samples criterion.

\subsection{Measurement Development}

Variable measurements in this study were developed based on some previous studies (Sayani \& Miniaoui, 2013; Eid \& El-Gohary, 2015; Kingshott et al., 2018; Meesala \& Paul, 2018). Four variable constructs had been employed, including religiosity, perceived value, customer satisfaction and trust. Twelve measurement items for religiosity were derived from Eid and ElGohary (2015), such as "In my personal life, religion is very important". Four measurement items of perceived value in this study were adapted from Islamic bank's specific variables (Sayani \& Miniaoui, 2013) e.g., "Islamic bank provides benefits which comply with the Islamic rules". Customer satisfaction measurement was adopted from Meesala and Paul (2018) e.g., "I am satisfied with the overall services of this bank". Finally, six measurement items of trust were taken from Kingshott et al. (2018), for example, "I feel that we can depend upon this bank as it is reliable". 


\subsection{Data Collection Procedures}

Some steps of the data collection procedure were implemented in this study. Firstly, the questionnaire development and translation from English to Bahasa Indonesia and vice-versa were conducted by using a back-translation procedure (Sekaran \& Bougie, 2013). The questionnaires in this study were measured by a five-point Likert' scale from Strongly disagree (1) to Strongly Agree (5). A pilot test to 30 respondents was conducted in this study. This pilot test aimed to make sure the items' clarity, wording, the relevancy of items, a bias of words and phrases and the questionnaire format (Lee, Chan, Chong, \& Thadani, 2018).

Furthermore, 400 responses were collected from four municipals/cities in West Sumatra which have Islamic bank branches (Darsono et al., 2017; Otoritas Jasa Keuangan, 2017). This study collected the data by using purposive sampling method (Sekaran \& Bougie, 2013). There were two criteria of the respondents, including (1) Islamic bank's customers, and (2) Customers who were actively doing transaction within the last three months. The second factor was applied because it was assumed that the customers had recent experience in doing the transaction and perceived the recent value of that Islamic bank services. Drop and collect data collection procedure was applied to this study where well-trained enumerators were employed for the data collection. To increase the response rate, we sent a formal letter from the university research center to the branch managers, and the branch managers helped the enumerators to contact the bank customers.

\subsection{Data Analysis}

For the data analysis, we used Covariance Based Structural Equation Modelling (CB-SEM). This study employed software package AMOS 24 as the program tools (Byrne, 2010). Some Goodness of Fit criteria (GoF) were used in this study, including Normed Chi-square (CMIN/DF), Comparative Fit Index (CFI), Tucker-Lewis Index (TLI), Adjusted Goodness of Fit Index (AGFI), Goodness of Fit Index(GFI) and Root Mean Square Error of Approximation (RMSEA) (Byrne, 2010). Those criteria have cut-off points, including CMIN/DF (<5), CFI, TLI and GFI which should be $\geq 0.90$, AGFI $(\geq 0.80)$ and RMSEA $(\leq 0.08)$ (Byrne, 2010). Besides, this study has also conducted some preliminary analyses, such as outliers, normality (Hair, Black, Babin, \& Anderson, 2010). It is found that the kurtosis value of each variable was between -3 and 3 . It means that the data was normal (DeCarlo, 1997). Multicollinearity and heteroscedasticity test have also been applied in this study. It was found that the variance inflation factor (VIF) values were less than 5. Hence, there was no multicollinearity problem. This study also applied Glejser test and found that there was heteroscedasticity problem (Hair et al., 2010). After the preliminary analyses, 390 usable questionnaires were used in this study.

Moreover, the validity and reliability test were deployed in this study. Construct reliability and validity are shown in Table 1 . We used some criteria including, loading factor value $>0.5$ as the criterion (Hair et al., 2010), Average Variance Extracted (AVE) value > 0.5, Cronbach's Alpha $>0.7$, and composite reliability (CR) > 0.7 (Hair, Sarstedt, Hopkins, \& G. Kuppelwieser, 2014). Table 1 shows that all constructs and items were valid and reliable because they have met the validity and reliability criteria. 
Table 1 Construct Validity and Reliability

\begin{tabular}{|c|c|c|c|c|c|c|c|}
\hline Constructs & Items & Mean & $\begin{array}{l}\text { Std. } \\
\text { Dev }\end{array}$ & Loading & $\alpha$ & $\mathbf{C R}$ & AVE \\
\hline \multirow[t]{9}{*}{ Religiosity } & & & & & 0.91 & 0.92 & 0.62 \\
\hline & In my personal life, religion is very important & 4.84 & 0.48 & 0.74 & & & \\
\hline & Islam helps me to have a better life & 4.78 & 0.47 & 0.82 & & & \\
\hline & The $D u a^{\prime}$ (supplication) supports me & 4.79 & 0.46 & 0.86 & & & \\
\hline & $\begin{array}{l}\text { The Prophet Muhammad (peace-be-upon- } \\
\text { him) is the role model for me. }\end{array}$ & 4.79 & 0.46 & 0.83 & & & \\
\hline & Performing Hajj is one of my main priorities & 4.74 & 0.49 & 0.71 & & & \\
\hline & I believe that Allah (God) helps me & 4.80 & 0.42 & 0.80 & & & \\
\hline & I perform all my prayers. & 4.66 & 0.55 & 0.64 & & & \\
\hline & I fast the whole month of Ramadan. & 4.69 & 0.54 & 0.63 & & & \\
\hline \multirow[t]{3}{*}{ Satisfaction } & & & & & 0.86 & 0.93 & $\mathbf{0 . 8 8}$ \\
\hline & $\begin{array}{l}\text { I am satisfied with the overall services of this } \\
\text { bank }\end{array}$ & 4.17 & 0.66 & 0.83 & & & \\
\hline & The services of this bank meet my expectation & 4.03 & 0.71 & 0.90 & & & \\
\hline \multirow{5}{*}{$\begin{array}{l}\text { Perceived } \\
\text { Value }\end{array}$} & & & & & 0.89 & 0.92 & 0.75 \\
\hline & $\begin{array}{l}\text { Islamic bank provides benefits which comply } \\
\text { with the Islamic rules. }\end{array}$ & 4.09 & 0.74 & 0.79 & & & \\
\hline & $\begin{array}{l}\text { This Islamic bank benefits me because it has } \\
\text { followed the Islamic law. }\end{array}$ & 3.96 & 0.74 & 0.90 & & & \\
\hline & $\begin{array}{l}\text { This Islamic bank benefits me because it has } \\
\text { followed the regulation from Central bank } \\
\text { Islamic board. }\end{array}$ & 4.03 & 0.71 & 0.82 & & & \\
\hline & $\begin{array}{l}\text { Islamic bank products benefit me because they } \\
\text { are compatible with the conventional bank } \\
\text { product and have complianced with the } \\
\text { Islamic rules. }\end{array}$ & 3.96 & 0.75 & 0.79 & & & \\
\hline \multirow[t]{6}{*}{ Trust } & & & & & 0.86 & 0.92 & 0.67 \\
\hline & $\begin{array}{l}\text { This bank has a consistent reputation for } \\
\text { honesty }\end{array}$ & 4.07 & 0.67 & 0.73 & & & \\
\hline & Our business is very secure with this bank & 4.1 & 0.66 & 0.74 & & & \\
\hline & $\begin{array}{l}\text { I get along well with this bank as it fulfils its } \\
\text { obligations }\end{array}$ & 3.9 & 0.71 & 0.77 & & & \\
\hline & $\begin{array}{l}\text { I feel that we can depend upon this bank as it } \\
\text { is reliable }\end{array}$ & 4.05 & 0.67 & 0.84 & & & \\
\hline & $\begin{array}{l}\text { I feel that this bank is "straight" with us and } \\
\text { shows respect }\end{array}$ & 4.03 & 0.69 & 0.82 & & & \\
\hline
\end{tabular}

This study used Fornell-Larcker's criterion to test the discriminant validity (Hair et al., 2014). Table 2 shows that it has met the discriminant validity because the square root of AVE of each construct was greater than the cross-loading value. Moreover, common method bias test was conducted because it was a cross-sectional study with self-rated questionnaires and had a potential common method bias problem (Podsakoff, MacKenzie, Lee, \& Podsakoff, 2003). The common method bias was tested by using Harman's single factor (MacKenzie \& Podsakoff, 2012). By using Exploratory Factor Analysis (EFA), it was found that the single factor variance extracted was $33.59 \%(<40 \%)$, hence, there was no common method bias (Abror, Patrisia, Trinanda, Omar 
Maznah, \& Wardi, 2020). Furthermore, analyzing the moderating effect hierarchical regression was employed in this study (Hair et al., 2010).

Table 2

Discriminant Validity Assessment for Research Variables

\begin{tabular}{llcll}
\hline Construct & $\mathbf{1}$ & $\mathbf{2}$ & $\mathbf{3}$ & $\mathbf{4}$ \\
\hline Religiosity & $\mathbf{0 . 8 4}$ & & & \\
Satisfaction & 0.24 & $\mathbf{0 . 9 4}$ & & \\
Perceived value & 0.15 & 0.49 & $\mathbf{0 . 8 7}$ & \\
Trust & 0.23 & 0.52 & 0.65 & $\mathbf{0 . 8 2}$ \\
\hline
\end{tabular}

Note: diagonal (in bold) is square root of AVE; ${ }^{* *}$ correlation is significant at the 0.01 level (2-tailed); *correlation is significant at the 0.05 level (2-tailed); for the discriminant validity, square root of AVE should be larger than off-diagonal elements

\section{Result}

The analysis in this study has been divided into three components (i.e., respondent profiles, the measurement model and the structural model) (Byrne, 2010). We discuss these three components as follows.

\subsection{Respondent Profiles}

The respondent profiles of this study were as follows: (1) most of them had a monthly expenditure of $\leq 7.5$ million rupiah $(96.9 \%)$, (2) they had transaction per month between 0 and 5 times $(99.5 \%)$, (3) $55.4 \%$ of respondents were women whose age were less than 40 years old (91.8\%), and (5) $64.9 \%$ respondents graduated from university. Accordingly, we may argue that the Islamic banks addressed people with a productive age and had a good education background as the customers.

\subsection{Measurement Model}

This study has examined the measurement model. Based on the Goodness of Fit (GoF) criteria, this study had a good fit measurement model. The value of CMIN/DF was $2.15(<5)$, the values of CFI, TLI and GFI were $0.96,0.96$ and 0.91 respectively $(\geq 0.90)$, value of AGFI was 0.89 ( $\geq$ $0.80)$, and value of RMSEA was $0.05(<0.08)$.

\subsection{Structural Model}

This study examined the GoF of the structural model. It is found that the value of CMIN/DF was $3.33(<5)$, values of CFI, TLI and GFI were $0.99,0.94$ and 0.99 respectively $(\geq 0.90)$, value of AGFI was $0.95(\geq 0.80)$ and value of RMSEA was $0.07(<0.08)$. Furthermore, Table 3 and Figure 1 show the hypothesis testing of this model. By using critical ratio alpha $1 \%$ and $5 \%$, it is found that religiosity had a significant direct impact on perceived value $(\mathrm{H} 1 ; \beta=0.13$; **). Religiosity also was a significant antecedent of satisfaction $(\mathrm{H} 2 ; \beta=0.18 ; * * *)$. Religiosity significantly 
influenced trust $(\mathrm{H} 3 ; \beta=0.12 ; * * *)$. Perceived value had a significant impact on satisfaction $(\mathrm{H} 4$; $\beta=0.47 ; * * *)$. Perceived value was a significant antecedent of trust $(\mathrm{H} 5 ; \beta=0.49 ; * * *)$. Satisfaction has significantly affected trust $\left(\mathrm{H} 6 ; \beta=0.24 ;{ }^{* * *}\right)$. Table 4 shows the results of the hierarchical regression analysis to examine the moderating effect of religiosity. It is found that religiosity had a significant moderating effect on the link between satisfaction and trust $(\mathrm{H} 7 ; \beta=$ $0.08 ; *)$. Finally, religiosity was also a significant moderating variable of the relationship between perceived value and trust $(\mathrm{H} 8 ; \beta=0.16 ; * * *)$.

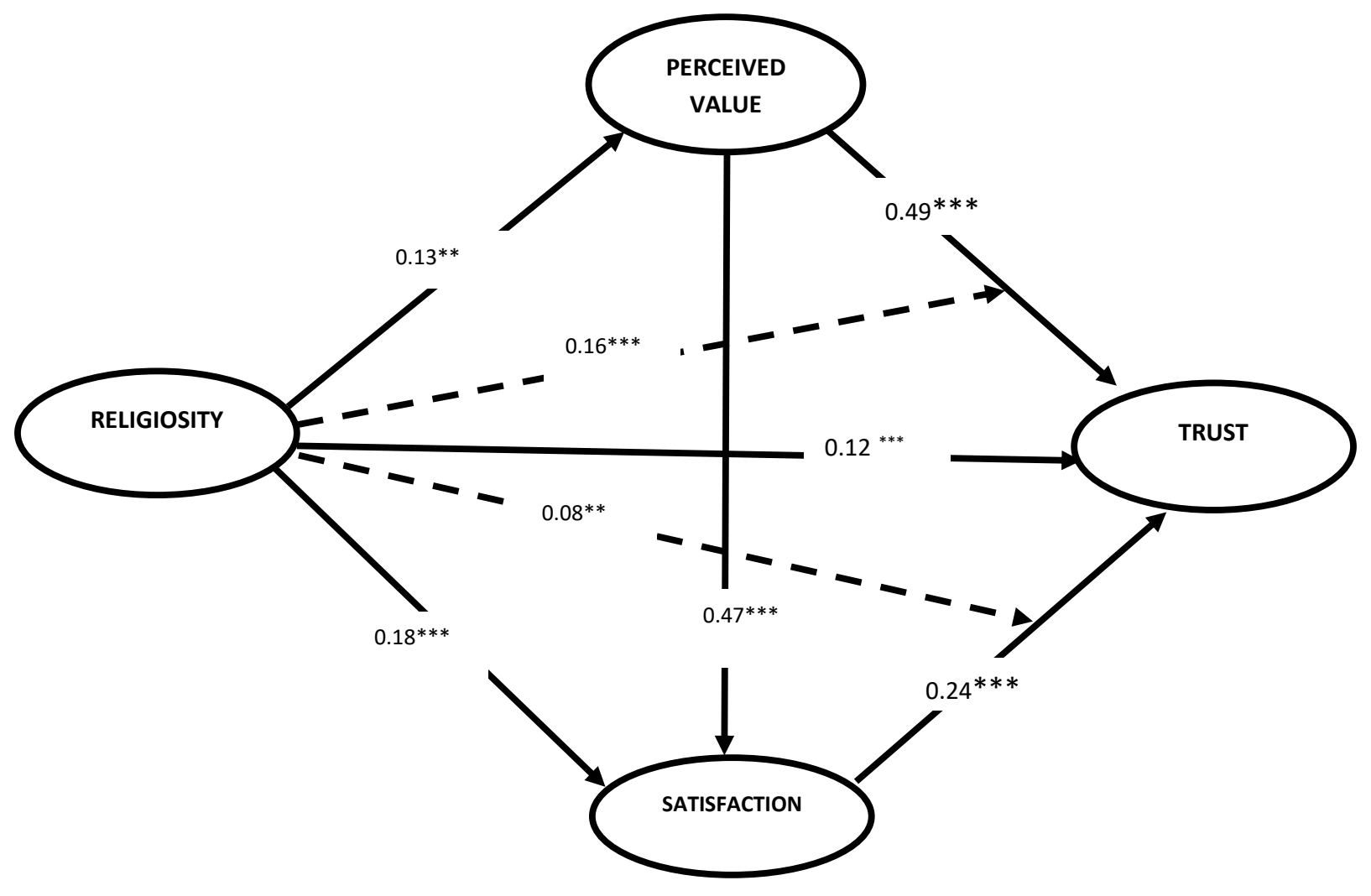

Figure 1. Research Model 
Table 3

Testing Results of Hypotheses

\begin{tabular}{lllll}
\hline Hypothesis & Predictor variable & Criterion variable & $\begin{array}{l}\text { Standardized } \\
\text { Path Coefficient } \\
(\boldsymbol{\beta})\end{array}$ & $\begin{array}{l}\text { Hypothesis } \\
\text { relationship }\end{array}$ \\
\hline H1 & Religiosity & Perceived value & $0.13^{* *}$ & Support \\
H2 & Religiosity & Satisfaction & $0.18^{* * *}$ & Support \\
H3 & Religiosity & Trust & $0.12^{* * *}$ & Support \\
H4 & Perceived value & Satisfaction & $0.47^{* * *}$ & Support \\
H5 & Perceived value & Trust & $0.49^{* * *}$ & Support \\
H6 & Satisfaction & Trust & $0.24^{* * *}$ & Support \\
\hline
\end{tabular}

Note: ${ }^{* * *} \mathrm{p}<0.01 ;{ }^{* *} \mathrm{p}<0.05 ; \mathrm{ns}=$ not significant

Table 4 Mediation Model

\begin{tabular}{|c|c|c|c|}
\hline Variable & Model 1 & Model 2 & Model 3 \\
\hline Intercept & -.010 & -.027 & -.031 \\
\hline Perceived value & $.518^{* * *}$ & $.507^{* * *}$ & $.486^{* * *}$ \\
\hline Satisfaction & $.250^{* * * *}$ & $.251^{* * * *}$ & $.243^{* * *}$ \\
\hline Religiosity & $.095^{* *}$ & $.108^{* * *}$ & $.124^{* * * *}$ \\
\hline \multicolumn{4}{|l|}{ Interaction } \\
\hline ReligiosityxSatisfaction & & $.077^{* *}$ & \\
\hline ReligiosityxPerceived value & & & $.155^{* * *}$ \\
\hline $\mathrm{R}^{2}$ & .485 & .490 & .508 \\
\hline F test & $121.107^{* * *}$ & $92.606^{* * *}$ & $99.489^{* * * *}$ \\
\hline
\end{tabular}

${ }^{* *} \mathrm{p}$ value $<0.01 ;{ }^{* *} \mathrm{p}$ value $<0.05 ; \mathrm{ns}=$ Not Significant; Trust as dependent variable

\section{Discussion}

This study found that religiosity has a significant impact on perceived value (H1). This finding supports previous studies conducted by Eid and El-Gohary (2015) and Amaliah et al. (2015) who found a moderating effect of religiosity on the perceived value relationship. Customer who has a higher religiosity will have a higher benefit standard for the product or service performance. 
Whilst, product or service benefit is related to customer perceived value. Accordingly, we argue that religiosity will increase the perceived value of the Islamic bank customer. When the customers of Islamic banks have high religiosity, presumably it will positively affect their perceived value on the Islamic bank services. Accordingly, it will increase their perception of Islamic bank service activities. Religiosity is also a positive and significant influence factor of customer satisfaction (H2). This finding is in line with some prior studies (Amaliah et al., 2015; Eid \& El-Gohary, 2015; Joshanloo, 2016). For example, Suhartanto et al. (2019) have found that religiosity has a significant impact on Halal food customer satisfaction. Joshanloo (2016) has also asserted a significant moderating effect of religiosity on the link between negative affect and life satisfaction. Moreover, Eid and El-Gohary (2015) have also highlighted the moderating effect of religiosity on the link between perceived value and customer satisfaction. Hence, it may argue that religiosity is a positive and significant antecedent of customer satisfaction. Therefore, when a customer has a higher religiosity, it will increase his/her satisfaction toward the Islamic bank.

This study also found that religiosity is as a significant influence factor of trust (H3). This finding supports previous studies done by Lo Turco and Maggioni (2018) who found that religiosity is a significant antecedent of bilateral trust in trade. The religiosity of a customer will influence their attitude which means that religiosity also has an impact on customer trust. When a customer has a higher religiosity, they will have a higher level of trust in the Islamic bank products. Moreover, perceived value has been found as a positive and significant antecedent of customer satisfaction (H4). This finding is congruent with some prior studies (El-Adly, 2018; Karjaluoto et al., 2018; Itani et al., 2019; Rahayu et al., 2020). For instance, Rahayu et al. (2020) have examined the impact of perceived value on customer trust. They found that a higher perceived value will lead to higher Islamic bank customer satisfaction. Accordingly, when the customers of Islamic bank perceived high value of Islamic bank products, they will have better satisfaction. Therefore, customer's perceived value is an important factor for an Islamic bank to increase customer satisfaction.

Perceived value also has a significant impact on customer trust (H5). This finding is similar to Itani et al. (2019); Sharma and Klein (2020) and Yuen et al. (2018) who investigated the link between perceived value and trust. For instance, Sharma and Klein (2020) have highlighted that a better-perceived value increases customer trust. When the customers of Islamic bank have perceived a better product or service value, they will also have a higher trust in the Islamic bank products or services. Customer satisfaction has been found as a significant and positive influence factor of trust (H6). This finding is in line with several prior studies Al-Ansi \& Han, 2019; Yao, Qiu, \& Wei, 2019; Al-Ansi, Olya, \& Han, 2018; Kingshott, Sharma, \& Chung, 2018). For example, Al-Ansi and Han (2019) found a significant link between satisfaction and trust. Islamic bank customers' trust will increase when they have satisfaction with the products. Accordingly, Islamic banks need to pay more attention to customers' satisfaction if they want to get customers' trust.

Furthermore, it was found that religiosity is a significant moderating variable of the link between perceived value and trust $(\mathrm{H} 7)$. This finding is in line with the previous studies which affirm that religiosity influences customers' attitudes and behaviors (Eid \& El-Gohary, 2015; Akhtar et al., 2020; Singh et al., 2021). Meanwhile, perceived value and trust are related to customers' attitude and behaviors. Despite the fact that these previous studies have not directly dealt with the moderating effect of religiosity on perceived value and trust as it is often disregarded, this study undoubtedly gives new insight and awareness of the roles of religiosity in customers' 
attitudes and behaviors. Customers will value the Islamic bank when they have high religiosity, and they will put their trust in the Islamic bank. Figure 2 shows the interaction effect of religiosity, perceived value and trust. When the Islamic bank customers have higher religiosity, it will strengthen the link between perceived value and trust.

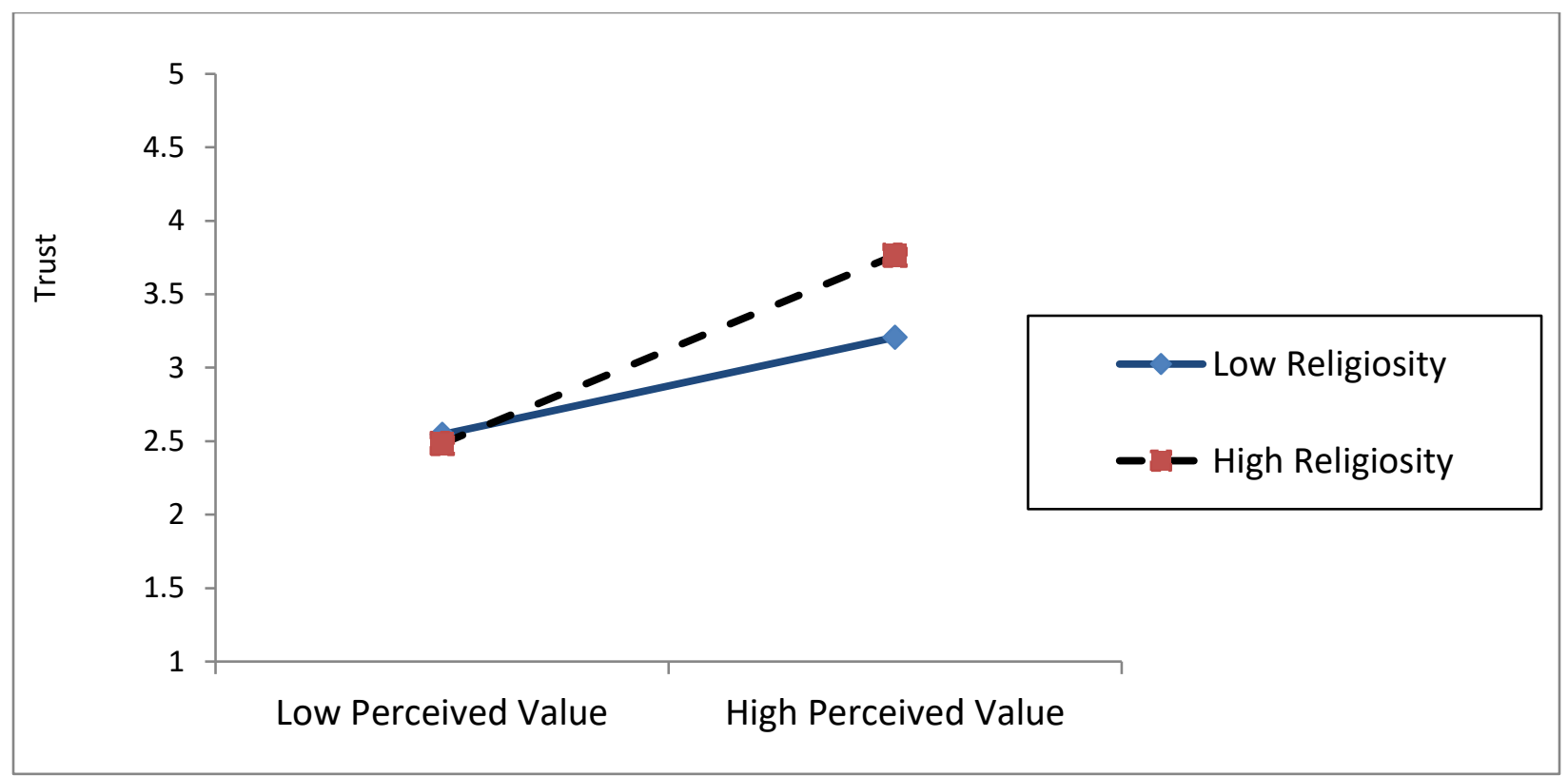

Figure 2. Interaction Effect of Religiosity, Perceived Value and Trust

Religiosity is also a significant moderating variable between satisfaction and trust (H8). This study strengthens the result of some previous researchers who claim that religiosity is related to customers' attitudes and behaviors (Eid \& El-Gohary, 2015; Akhtar et al., 2020; Singh et al., 2021). Akhtar et al. (2020), for instance, have confirmed the moderating role of religiosity on customer's attitude. Despite the fact that the previous studies have not noticed the moderating effect of religiosity on the relationship between satisfaction and trust, this study has revealed that religiosity plays significant role as moderating variable on satisfaction and trust relationship. Accordingly, the satisfaction level of the Islamic bank customers will be affected by their religiosity which cements the relationship between customers' satisfaction and trust. In other words, The relationship between satisfaction and trust will be consolidated for the customer with high religiosity. The interaction effect of religiosity, customers' satisfaction and trust is demonstrated in Figure 3. . 


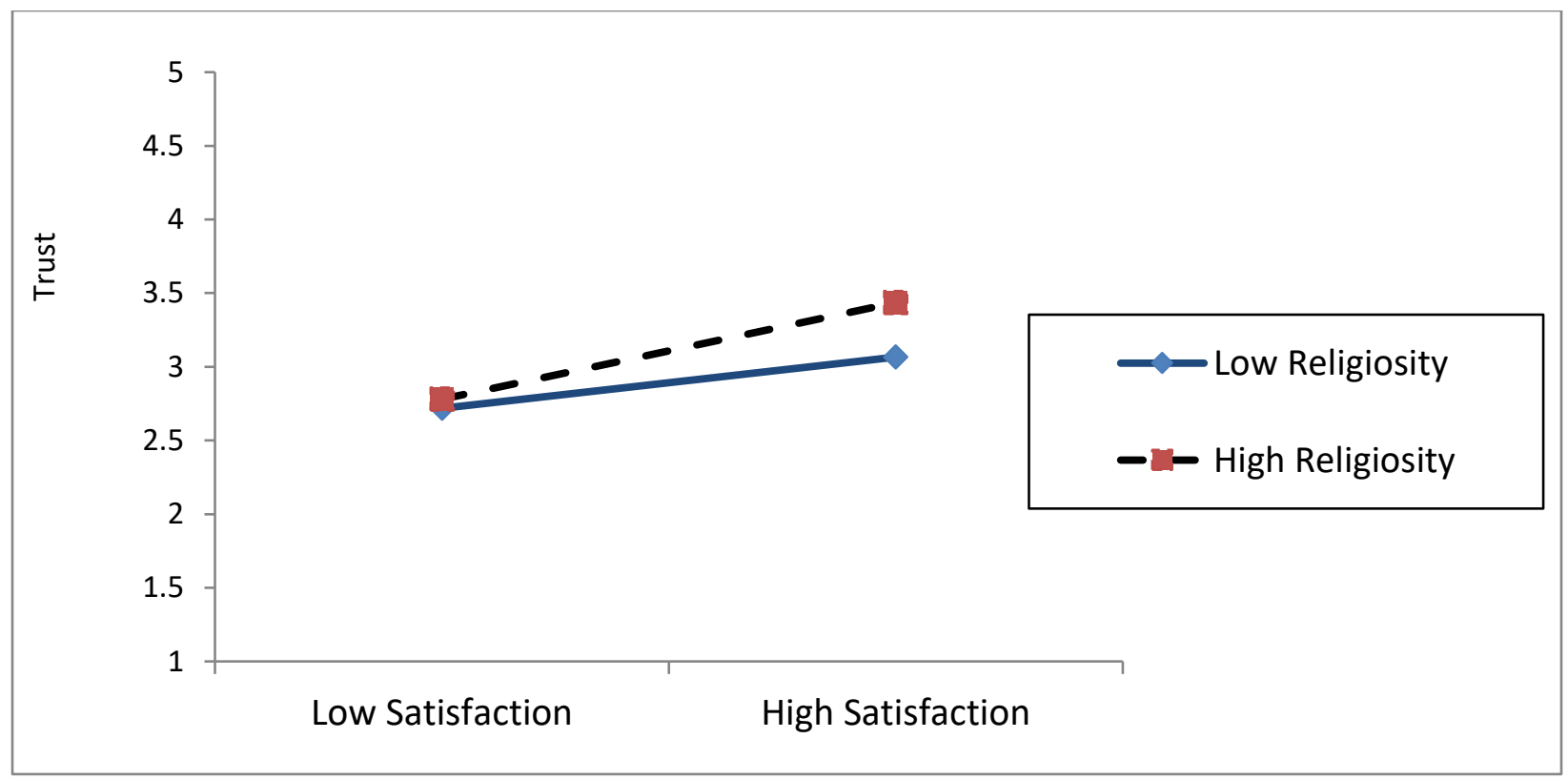

Figure 3. Interaction Effect of Religiosity, Customer Satisfaction and Trust

\section{Conclusion}

This study has found some significant relationships between religiosity and trust. This research reveals its contributions, including theoretical contributions and managerial implication. Theoretical contributions of this study are:

1) The relationships between religiosity and trust have been examined in a more comprehensive model which is overlooked in the previous studies.

2) It revealed a significant moderating role of religiosity on the link between perceived value and trust. To the best of our knowledge, this relationship is limited previously. Accordingly, it gives a new insight into this relationship.

3) This study has also highlighted the moderating role of religiosity on the relationship between customers' satisfaction and trust. This relationship is also neglected previously. Hence, this study has revealed new insight into this relationship.

4) In contributing to knowledge, the results of this study are added to other studies in the field of Islamic marketing for Islamic financial institutions.

Furthermore, this study contributes to the managerial implication. The Islamic bank managers will consider religiosity, perceived value and customers' satisfaction to increase customers' trust. For example, to increase customers' trust, the Islamic bank companies have to comply with Islamic law and improve their services which are compatible with the conventional bank. Hence, it will increase the customers' satisfaction and arguably it will lead to customers' trust and loyalty in the future. This study explains the factors that make customers put their trust in Islamic banks, and conventional banks and institutions which desire to convert to the Islamic banking system can have the benefit of the results of this study. In addition, relationship between perceived value, customers' satisfaction and trust is greatly affected by religiosity of the customers. Hence, in order to provide great service to customers, the Islamic banks have to enforce their compliance with the Islamic law to gain more customers' perceived value, satisfaction which will 
lead to customers' trust. Therefore, this study provides recommendations in which an Islamic bank can bridge the gap between theory and practice from the clients' point of view. Moreover, this study also contributes to the regulators such as Central Bank to increase the Islamic bank customer's trust. This also has an impact on society by increasing the customers' trust which will lead to the market share of Islamic banks in Indonesia and raise their position in the financial market.

This study has revealed some contributions; however, it also has some limitations. Firstly, it is a cross-sectional study; thus, this study only captures the phenomena in one time and the results cannot be generalized to all customers. Accordingly, for the future study, it may expand to a longitudinal study. Secondly, this study is only from one country perspective; hence, for future research, it can be extended to some countries such as Southeast Asia countries. Finally, this study is only focused on the antecedents of trust. Accordingly, some consequences of trust such as loyalty and value co-creation can be addressed in the future.

\section{REFERENCES}

Abror, A., Patrisia, D., Engriani, Y., Evanita, S., Yasri, Y., \& Dastgir, S. (2019). Service quality, religiosity, customer satisfaction, customer engagement and Islamic bank's customer loyalty. Journal of Islamic Marketing, 11(6), 1691-1705. doi: 10.1108/jima-03-2019-0044

Abror, A., Patrisia, D., Trinanda, O., Omar Maznah, W., \& Wardi, Y. (2020). Antecedents of word of mouth in Muslim-friendly tourism marketing: the role of religiosity. Journal of Islamic Marketing, aheadof-print(ahead-of-print). doi: 10.1108/jima-01-2020-0006

Abror, A., Wardi, Y., Trinanda, O., \& Patrisia, D. (2019). The impact of Halal tourism, customer engagement on satisfaction: moderating effect of religiosity. Asia Pacific Journal of Tourism Research, 24(7), 633-643. doi: 10.1080/10941665.2019.1611609

Achour, M., Mohd Nor, M. R., \& MohdYusoff, M. Y. Z. (2016). Islamic Personal Religiosity as a Moderator of Job Strain and Employee's Well-Being: The Case of Malaysian Academic and Administrative Staff. Journal of Religion and Health, 55(4), 1300-1311. doi: 10.1007/s10943-0150050-5

Agarwala, R., Mishra, P., \& Singh, R. (2019). Religiosity and consumer behavior: a summarizing review. Journal of Management, Spirituality \& Religion, 16(1), 32-54. doi: 10.1080/14766086.2018.1495098

Aji, H. M., Muslichah, I., \& Seftyono, C. (2020). The determinants of Muslim travellers' intention to visit non-Islamic countries: a halal tourism implication. Journal of Islamic Marketing, ahead-of$\operatorname{print}($ ahead-of-print). doi: 10.1108/jima-03-2020-0075

Akhtar, N., Jin, S., Alvi, T. H., \& Siddiqi, U. I. (2020). Conflicting halal attributes at halal restaurants and consumers' responses: The moderating role of religiosity. Journal of Hospitality and Tourism Management, 45, 499-510. doi: https://doi.org/10.1016/j.jhtm.2020.10.010

Al-Ansi, A., \& Han, H. (2019). Role of halal-friendly destination performances, value, satisfaction, and trust in generating destination image and loyalty. Journal of Destination Marketing \& Management, 13, 51-60. doi: https://doi.org/10.1016/j.jdmm.2019.05.007

Al-Ansi, A., Olya, H. G. T., \& Han, H. (2018). Effect of general risk on trust, satisfaction, and recommendation intention for halal food. International Journal of Hospitality Management. doi: https://doi.org/10.1016/j.ijhm.2018.10.017 
Alalwan, A. A., Dwivedi, Y. K., \& Rana, N. P. (2017). Factors influencing adoption of mobile banking by Jordanian bank customers: Extending UTAUT2 with trust. International Journal of Information Management, 37(3), 99-110. doi: https://doi.org/10.1016/j.ijinfomgt.2017.01.002

Amaliah, I., Aspiranti, T., \& Purnamasari, P. (2015). The Impact of the Values of Islamic Religiosity to Islamic Job Satisfaction in Tasikmalaya West Java, Indonesia, Industrial Centre. Procedia - Social and Behavioral Sciences, 211, 984-991. doi: https://doi.org/10.1016/j.sbspro.2015.11.131

Aw Eugene, C.-X., Basha Norazlyn, K., Ng Siew, I., \& Sambasivan, M. (2019). To grab or not to grab? The role of trust and perceived value in on-demand ridesharing services. Asia Pacific Journal of Marketing and Logistics, 31(5), 1442-1465. doi: 10.1108/APJML-09-2018-0368

Aziz, S., Md Husin, M., Hussin, N., \& Afaq, Z. (2019). Factors that influence individuals' intentions to purchase family takaful mediating role of perceived trust. Asia Pacific Journal of Marketing and Logistics, 31(1), 81-104. doi: 10.1108/APJML-12-2017-0311

Bakar, A., Lee, R., \& Rungie, C. (2013). The effects of religious symbols in product packaging on Muslim consumer responses. Australasian Marketing Journal (AMJ), 21(3), 198-204. doi: https://doi.org/10.1016/j.ausmj.2013.07.002

Bègue, L. (2002). Beliefs in justice and faith in people: just world, religiosity and interpersonal trust. Personality and Individual Differences, 32(3), 375-382. doi: https://doi.org/10.1016/S0191$\underline{8869(00) 00224-5}$

Bonsón Ponte, E., Carvajal-Trujillo, E., \& Escobar-Rodríguez, T. (2015). Influence of trust and perceived value on the intention to purchase travel online: Integrating the effects of assurance on trust antecedents. Tourism Management, 47, 286-302. doi: https://doi.org/10.1016/j.tourman.2014.10.009

Briliana, V., \& Mursito, N. (2017). Exploring antecedents and consequences of Indonesian Muslim youths' attitude towards halal cosmetic products: A case study in Jakarta. Asia Pacific Management Review, 22(4), 176-184. doi: https://doi.org/10.1016/j.apmrv.2017.07.012

Byrne, B. M. (2010). Structural Equation Modeling With AMOS: Basic concepts, applications, and programming, second edition. GB: Routledge Ltd.

Carlson, J., Rahman, M. M., Taylor, A., \& Voola, R. (2017). Feel the VIBE: Examining value-in-the-brandpage-experience and its impact on satisfaction and customer engagement behaviours in mobile social media. Journal of Retailing and Consumer Services. doi: https://doi.org/10.1016/j.jretconser.2017.10.002

Cheshin, A., Amit, A., \& van Kleef, G. A. (2018). The interpersonal effects of emotion intensity in customer service: Perceived appropriateness and authenticity of attendants' emotional displays shape customer trust and satisfaction. Organizational Behavior and Human Decision Processes, 144, 97 111. doi: https://doi.org/10.1016/j.obhdp.2017.10.002

Darsono, Sakti, A., Suryanti, E. T., Astiyah, S., \& Darwis, A. (2017). Masa Depan Keuangan Syariah Indonesia (M. S. Antonio Ed.). Jakarta, Indonesia: Tazkia Publishing kerjasama Bank Indonesia.

DeCarlo, L. T. (1997). On the meaning and use of kurtosis. Psychological Methods, 2(3), 292-307. doi: http://dx.doi.org/10.1037/1082-989X.2.3.292

Eid, R., \& El-Gohary, H. (2015). The role of Islamic religiosity on the relationship between perceived value and tourist satisfaction. Tourism Management, 46(Supplement C), 477-488. doi: https://doi.org/10.1016/j.tourman.2014.08.003

El-Adly, M. I. (2018). Modelling the relationship between hotel perceived value, customer satisfaction, and customer loyalty. Journal of Retailing and Consumer Services. doi: https://doi.org/10.1016/j.jretconser.2018.07.007

Fungáčová, Z., Hasan, I., \& Weill, L. (2019). Trust in banks. Journal of Economic Behavior \& Organization, 157, 452-476. doi: https://doi.org/10.1016/j.jebo.2017.08.014

Gursoy, D., Altinay, L., \& Kenebayeva, A. (2017). Religiosity and entrepreneurship behaviours. International Journal of Hospitality Management, 67, 87-94. doi: https://doi.org/10.1016/j.ijhm.2017.08.005 
Hair, J. F., Black, W. C., Babin, B. J., \& Anderson, R. E. (2010). Multivariate data analysis. New Jersey: Prentice Hall.

Hair , J. F. J., Sarstedt, M., Hopkins, L., \& G. Kuppelwieser, V. (2014). Partial least squares structural equation modeling (PLS-SEM). European Business Review, 26(2), 106-121. doi: doi:10.1108/EBR-10-2013-0128

Itani, O. S., Kassar, A.-N., \& Loureiro, S. M. C. (2019). Value get, value give: The relationships among perceived value, relationship quality, customer engagement, and value consciousness. International Journal of Hospitality Management, $80, \quad 78-90 . \quad$ doi: https://doi.org/10.1016/j.ijhm.2019.01.014

Jamal, A., \& Sharifuddin, J. (2015). Perceived value and perceived usefulness of halal labeling: The role of religion and culture. Journal of Business Research, 68(5), 933-941. doi: https://doi.org/10.1016/j.jbusres.2014.09.020

Jamshidi, D., \& Hussin, N. (2016). Forecasting patronage factors of Islamic credit card as a new ecommerce banking service: An integration of TAM with perceived religiosity and trust. Journal of Islamic Marketing, 7(4), 378-404. doi: 10.1108/JIMA-07-2014-0050

Jeong, Y., \& Kim, S. (2019). A study of event quality, destination image, perceived value, tourist satisfaction, and destination loyalty among sport tourists. Asia Pacific Journal of Marketing and Logistics, 32(4), 940-960. doi: 10.1108/APJML-02-2019-0101

Joshanloo, M. (2016). Religiosity moderates the relationship between negative affect and life satisfaction: A study in 29 European countries. Journal of Research in Personality, 61, 11-14. doi: https://doi.org/10.1016/j.jrp.2016.01.001

Karjaluoto, H., Shaikh, A. A., Saarijärvi, H., \& Saraniemi, S. (2018). How perceived value drives the use of mobile financial services apps. International Journal of Information Management. doi: https://doi.org/10.1016/j.ijinfomgt.2018.08.014

Kasiri, L. A., Guan Cheng, K. T., Sambasivan, M., \& Sidin, S. M. (2017). Integration of standardization and customization: Impact on service quality, customer satisfaction, and loyalty. Journal of Retailing and Consumer Services, 35, 91-97. doi: https://doi.org/10.1016/j.jretconser.2016.11.007

Kingshott, R. P. J., Sharma, P., \& Chung, H. F. L. (2018). The impact of relational versus technological resources on e-loyalty: A comparative study between local, national and foreign branded banks. Industrial Marketing Management, $\quad 72, \quad 48-58 . \quad$ doi: https://doi.org/10.1016/j.indmarman.2018.02.011

Konuk, F. A. (2018). The role of store image, perceived quality, trust and perceived value in predicting consumers' purchase intentions towards organic private label food. Journal of Retailing and Consumer Services, 43, 304-310. doi: https://doi.org/10.1016/j.jretconser.2018.04.011

Lee, Z. W. Y., Chan, T. K. H., Chong, A. Y.-L., \& Thadani, D. R. (2018). Customer engagement through omnichannel retailing: The effects of channel integration quality. Industrial Marketing Management. doi: https://doi.org/10.1016/j.indmarman.2018.12.004

Liu, R. L., \& Minton, E. A. (2018). Faith-filled brands: The interplay of religious branding and brand engagement in the self-concept. Journal of Retailing and Consumer Services, 44, 305-314. doi: https://doi.org/10.1016/j.jretconser.2018.07.022

Lo Turco, A., \& Maggioni, D. (2018). Effects of Islamic religiosity on bilateral trust in trade: The case of Turkish exports. Journal of Comparative Economics, 46(4), 947-965. doi: https://doi.org/10.1016/j.jce.2018.02.001

MacKenzie, S. B., \& Podsakoff, P. M. (2012). Common method bias in marketing: causes, mechanisms, and procedural remedies. Journal of Retailing, 88(4), 542-555. doi: 10.1016/j.jretai.2012.08.001

Meesala, A., \& Paul, J. (2018). Service quality, consumer satisfaction and loyalty in hospitals: Thinking for the future. Journal of Retailing and Consumer Services, 40, 261-269. doi: https://doi.org/10.1016/j.jretconser.2016.10.011

Minton, E. A. (2019). Believing is buying: religiosity, advertising skepticism, and corporate trust. Journal of Management, Spirituality \& Religion, 16(1), 54-75. doi: 10.1080/14766086.2018.1437764 
Miranda, S., Tavares, P., \& Queiró, R. (2017). Perceived service quality and customer satisfaction: A fuzzy set QCA approach in the railway sector. Journal of Business Research. doi: https://doi.org/10.1016/j.jbusres.2017.12.040

Otoritas Jasa Keuangan. (2017). Financial Service Literacy and Inclusive National Survey 2016. Jakarta: Otoritas Jasa Keuangan.

Otoritas Jasa Keuangan. (2019). Sharia Banking Statistics March 2019. Jakarta: Otoritas Jasa Keuangan.

Podsakoff, P. M., MacKenzie, S. B., Lee, J.-Y., \& Podsakoff, N. P. (2003). Common method biases in behavioral research: A critical review of the literature and recommended remedies. Journal of Applied Psychology, 88(5), 879-903. doi: 10.1037/0021-9010.88.5.879

Rahayu, Y. S., Setiawan, M., Irawanto, D. W., \& Rahayu, M. (2020). Muslim customer perceived value on customer satisfaction and loyalty: Religiosity as a moderation. Management Science Letters, 10111016. doi: $10.5267 /$ j.msl.2019.11.009

Sayani, H., \& Miniaoui, H. (2013). Determinants of bank selection in the United Arab Emirates. International Journal of Bank Marketing, 31(3), 206-228. doi: doi:10.1108/02652321311315302

Sekaran, U., \& Bougie, R. (2013). Research methods for business: a skill-building approach. Chichester; Hoboken, N.J: Wiley.

Sharma, V. M., \& Klein, A. (2020). Consumer perceived value, involvement, trust, susceptibility to interpersonal influence, and intention to participate in online group buying. Journal of Retailing and Consumer Services, 52, 101946. doi: https://doi.org/10.1016/j.jretconser.2019.101946

Singh, J., Singh, G., Kumar, S., \& Mathur, A. N. (2021). Religious influences in unrestrained consumer behaviour. Journal of Retailing and Consumer Services, 58, 102262. doi: https://doi.org/10.1016/j.jretconser.2020.102262

Suhartanto, D., Marwansyah, M., Muflih, M., Najib Moh, F., \& Faturohman, I. (2019). Loyalty formation toward Halal food: Integrating the Quality-Loyalty model and the Religiosity-Loyalty Model. British Food Journal, 122(1), 48-59. doi: 10.1108/BFJ-03-2019-0188

Suryani. (2015). Customers' perceived value towards the service in Islamic banking: Confirmatory factor analysis. Journal of Economics, Business, and Accountancy Ventura, 18(2), 201-212. doi: 10.14414/jebav.v18i2.448

Vera, J., \& Trujillo, A. (2013). Service quality dimensions and superior customer perceived value in retail banks: An empirical study on Mexican consumers. Journal of Retailing and Consumer Services, 20(6), 579-586. doi: https://doi.org/10.1016/j.jretconser.2013.06.005

Wongkitrungrueng, A., \& Assarut, N. (2018). The role of live streaming in building consumer trust and engagement with social commerce sellers. Journal of Business Research. doi: https://doi.org/10.1016/j.jbusres.2018.08.032

Yao, T., Qiu, Q., \& Wei, Y. (2019). Retaining hotel employees as internal customers: Effect of organizational commitment on attitudinal and behavioral loyalty of employees. International Journal of Hospitality Management, 76, 1-8. doi: https://doi.org/10.1016/j.ijhm.2018.03.018

Yasin, M., Liébana-Cabanillas, F., Porcu, L., \& Kayed, R. N. (2020). The role of customer online brand experience in customers' intention to forward online company-generated content: The case of the Islamic online banking sector in Palestine. Journal of Retailing and Consumer Services, 52, 101902. doi: https://doi.org/10.1016/j.jretconser.2019.101902

Yuen, K. F., Wang, X., Wong, Y. D., \& Zhou, Q. (2018). The effect of sustainable shipping practices on shippers' loyalty: The mediating role of perceived value, trust and transaction cost. Transportation Research Part E: Logistics and Transportation Review, 116, 123-135. doi: https://doi.org/10.1016/j.tre.2018.06.002

Zamani-Farahani, H., \& Musa, G. (2012). The relationship between Islamic religiosity and residents' perceptions of socio-cultural impacts of tourism in Iran: Case studies of Sare'in and Masooleh. Tourism Management, 33(4), 802-814. doi: https://doi.org/10.1016/j.tourman.2011.09.003

Zhang, L., Yan, Q., \& Zhang, L. (2018). A computational framework for understanding antecedents of guests' perceived trust towards hosts on Airbnb. Decision Support Systems, 115, 105-116. doi: https://doi.org/10.1016/j.dss.2018.10.002 